\title{
JUDICIAL REGULATION OF RATES OF WAGE FOR WOMEN ${ }^{1}$
}

\author{
W. JETHRo Brown \\ President of the Industrial Court, South Australia
}

Probably no problem of industrial regulation is of more immediate importance than the question of the rates of wage for women. It has been my fortune, or misfortune, to deal with the question judicially in the Industrial Court of the State of South Australia. ${ }^{2}$ The present article is based upon my judgment in that case. I felt, and I still feel, that it was desirable to explain what appeared to me the fundamental principles which should guide an Industrial Court in dealing with a subject which is of growing importance, involves manifold issues, and affects the interests of all classes of the community. So far as I am aware, the subject has not previously received judicial consideration in other countries. It has on various occasions come before Industrial Courts in Australia; and certain definite principles may be found in the brochure by Mr. Justice Higgins on $A$ New Province for Law and Order. The principles in question are as follows:-

(I) "The principle of the living wage has been applied to women, but with a difference, as women are not usually legally responsible for the maintenance of a family. A woman's minimum is based on the average cost of her own living to one who supports herself by her own exertions. A woman or girl with a comfortable home cannot be left to underbid in wages other women or girls who are less fortunate.

(2) "But in an occupation in which men as well as women are employed, the minimum is based on a man's cost of living. If the occupation is that of a blacksmith, the minimum is a man's minimum; if the occupation is that of a milliner, the minimum is a woman's minimum; in the occupation of fruit-picking, as both men and women are employed, the minimum must be a man's minimum."

I hope I may say without presumption that there is much that might De justly urged in support of these principles, apart from the authority

\footnotetext{
${ }^{1}$ [This article is expected to appear in the AUSTRalian QuARTERLy for December, I9I8 or January, 1919. With the consent of the Editor of that magazine, it was sent by the author for publication also in the Yale LAw JouRnal. It is highly desirable that such a paper should receive a wider circulation in America than can be commanded by a magazine published in Australia for Australian readers. We therefore take pleasure in printing it for our readers, and the more so because of the previous publication of the learned author's article "The Judicial Regulation of Industrial Conditions," which appeared in (IgI8) 27 YaLE LAW JouRNaL, 427.-ED.]

"The Printing Trades Case (I917) Nos. 53-54.
} 
which properly attaches to them as declaratory of the policy of the Commonwealth Court of Conciliation and Arbitration. In particular, their clearness, and the comparative ease of their application to particular industries, must appeal to a Judge of an Industrial Court. But, in the recent case the far-reaching importance of the subject imposed upon me the necessity of an analysis of the principles with a view to considering the propriety of their adoption by this Court. I defer any remarks which may appear to me pertinent to the first of the principles affirmed by the learned Judge until I come to deal with the statutory definition of the living wage as stated in the South Australian Industrial Arbitration Act of I9I2. The second principle suggests a partial recognition of the alluring doctrine of equal pay for equal work. But I am more inclined to regard it as merely a rule of expediency designed to protect men from unfair competition in the labor market. Indeed, if we were to accept the "equal pay for equal work" doctrine, it is hard to say why the minimum wage for all unskilled women workers should not be the same, or approximately the same, as that for unskilled men. Women, who are unskilled workers, may naturally ask why their rate of wage should depend upon the accident of men happening to be employed in the same industry. Certainly some women to-day ask why the wages of women should not be assessed from the point of view of effort expended irrespective of whether women do or do not compete with men for employment. Other women take a more definite stand, and urge the award of equal pay for equal work in value. Such modes of assessment, however, have not been generally adopted by Industrial Courts. What is the explanation? One answer is that, however theoretically desirable, it is practically impossible for a mere human being to fix wages by reference to the value of work done. The impossibility is especially apparent in cases of mental work, because of its infinite variety. Milton, if I remember rightly, obtained $f_{5}$ for the manuscript of Paradise Lost. It has been said that an American scientist, working at a fixed salary, made among many other discoveries, one discovery which increased the value of the potato crop of the United States by the amount of $£ 2,000,000$ per annum. While the remunerations received in the cases mentioned were obviously capricious, and suggest that the question of value of work done ought not to be wholly ignored, it remains true that an Industrial Court which should set out to fix the minimum wage for unskilled labor by reference to the value of the work done, would be soon lost in a sea of fallacy and contradiction. Even an employer in a particular business would be generally unable to assess in terms of money the values of particular workers, though he might be able to say what the total wages bill ought to be if his business is to prove a paying proposition. As far as unskilled labor is concerned, an Industrial Judge is naturally driven to adopt the standard of the needs of the worker-a standard which leads to different results as regards men and women. The man, and not the 
woman, is typically the bread-winner of a family. In the case recently before me Sir Josiah Symon, K. C., in his learned argument on behalf of women worker's, urged that the wage for men was a personal and not a family wage. He contended that the possibility that a man might have a family to support, though a possibility, did not affect the essentially personal character of the wage. He was unable to do more than acquiesce in my suggestion that his argument led to the conclusion that marriage was a calamity, which, like sickness, disease, or sudden death, might happen to any man! I am quite unable to accept the learned counsel's argument. I look upon the maintenance of home life as of supreme importance to the community. I regard the wage paid to the adult male as essentially and in substance a family wage. True, so far as single men are concerned, it has long been settled in Australia that the minimum (living) wage should not be less than that of the married man. In other words, in discussing the needs of the male worker, a man with a family to support has been taken as the basis of assessment. Any other conclusion would prejudice the married man in search of employment, would tend to produce sterility of the population, and would place the Industrial Court in the invidious position of fixing wages at a rate which would make it difficult, if not impossible, for single men to save something for the time when they may have the felicity to become supporters of a family. Of course, some men never marry, and, in their case, the application of the doctrine of equal pay for equal work produces results which might be rectified by some such device as the bachelor tax. But many of the reasons which apply in support of the doctrine of equal pay for. equal work as applied to men (whether married or single) do not apply to employees (male or female). When women marry, they do so, I will not say with the object, but I may say with the contemplation, of being supported. As Mr. Justice Cussen says: "The ordinary wife and mother has fortunately other duties to perform, the value of which is not assessable by determination."3 There is another reason for limiting the doctrine of equal pay for equal work to men, and that is the probability that a larger proportion of single men than of single women have to support parents or other relatives. In the net result, the abstract doctrine of equal pay for equal work, despite its plausibility, must, in a world full of complexities and imperfections, yield to considerations of practical expediency. As I have pointed out, carried to its logical conclusion, the doctrine implies that all women who work for their livelihood should be paid a wage assessed by reference to the value of the work done, and irrespective of the traditional social structure which imposes on men the duty of maintaining the home. "Can one justify levelling up woman's wages to men's in trades where they both work, while keeping them on an altogether lower scale in

I9 Argus L. Rep. 147. 
wholly feminine trades of equivalent difficulty?" asks Eleanor Rathbone. ${ }^{*}$ The plain, if regrettable, fact is that the determination of rates of wage according to the value of the work done is only possible in one or other limited senses. For example, in assessments of the living wage, although the standard of assessment be the reasonable needs of the workers, an Industrial Court cannot properly interpret the elastic expression "reasonable needs" without some reference to the value of the workers as measured by the wealth of the community, its total output, etc. ${ }^{5}$ Further, it may be possible for a Court to say that if a laborer in grade " $X$ " receives $t_{3}$ per week, the laborer in grade " $Y$ " should receive $f 3$ plus or minus some specified amount. But that is not to say that the value of the work of the laborer in grade " $X$ " is or is not \$3 per week-either from the point of view of the employer or that of the community. In the course of the hearing of the recent case, I asked the learned counsel for the employees to distinguish between the value of the services of the navvy on the road and those of the cook in the home. As the learned counsel was precluded, by the nature of the employees' log, from appealing to supply and demand, he had to avow his inability to distinguish between the values. I proceeded to point out that, assuming, for the sake of argument, that the services were of equal value, it would follow that the cook should receive $36 s$. 6d. a week (allowing I7s. 6d. for board and residence) as an absolute bed-rock level. As a matter of fact, since cooking is (or at least ought to be) a skilled occupation, the wage to the cook, accepting the test of the value of work done, and allowing for marginal differences, should be between $t_{2}$ and $f_{3}$ per week. On various grounds $I$ am drawn to the conclusion that Mr. Justice Higgins, in affirming equal pay to men and women in "ambiguous occupations," was not influenced by the abstract doctrine which I have been considering, but by the practical difficulty of preventing men from being competed out of employment by cheap female labor. Indeed, the ardent advocate of "equal pay for equal work" as a supreme and axiomatic principle for determining the rates of wage for women, ignores the just claim of the "industrial mother". Of course, the State might endow the married woman; but the propriety of doing so is not for a judicial tribunal to consider.

No one would deny the need for recognising the danger of men being competed out of employment by cheap female labor. Few would deny that women workers, whether living at home or not, should receive at least a living wage for unskilled labor, and should also receive a secondary wage for skill, \&c. But even assuming all this, the practical difficulties which confronted me when I was asked to apply the second principle of Mr. Justice Higgins to the facts of industrial

- Economic Journal (March, I917) 65.

'Carpenters' and Joirers' Case (1916-1918) S. A. I. R. 172-178. 
life were so disturbing as to call for a brief statement. The first of these difficulties is that the principle involves an embarrassing dilemma. In industries in which both men and women find employment, women either are or are not typically on the same level as men as far as usefulness to the employer is concerned. If they are not typically equal to men, then, under normal conditions of the labor market, they are liable to be excluded from employments for which they may be well adapted. In other words, under the conditions suggested, an Industrial Court, while purporting to confer a boon on women, would be really excluding them from at least some avenues of employment. On the other hand, in industries where men and women are approximately of equal value, then, as a result of the general increase in the wages bill of the community, the purchasing value of the wages of men would be affected. The wages bill of the community, as well as any surplus for profits, comes out of prices. A high rate of wages to women, in proportion to the number of women affected, means that the breadwinner with a wife and family to support will contribute as a consumer, in order to maintain women workers in a far higher standard of living than is possible for the man himself, his wife, and children. The second principle of Mr. Justice Higgins thus involves an embarrassing dilemma. I fear that the existence of the dilemma is seldom realised. Men and women employees alike are apt to be obsessed by the doctrine of equal pay for equal work, without considering ultimate consequences. A cynic might suggest that the men are so confident of holding their own that they believe that the fixation of equal pay would practically ensure to men a monopoly of the employments in which they happen to be engaged. Undoubtedly, however, many men are actuated by more chivalrous motives. But the motives, bad or good, must be brought under the cold light of reason. In the case recently before me Mr. Parsons, K. C., speaking on behalf of the employers, argued with great cogency, "The mere fact that women are doing a part of the work hitherto done by men, shows the capacity of women for the occupations concerned. It is economically unsound to retain men in an employment, at 'artificial wages', when women are willing to do the work for 'naţural wages'. Men cannot complain if they are driven out of the field of what has really become women's employment. . . To declare that women shall compete only on the terms fixed for a man's wage is unfair to the public, because such an artificial stipulation must increase the cost of living. . . . There is a danger of retaining men in work for which they have ceased to be in demand, and in which they can be retained only by payments of artificial wages to the injury of many women and the public. . . . As the introduction of machinery deprived men of some employment, so may women. In both cases there are regrettable consequences, but the community in the long run gains." 
The use of the term "artificial wages" by the learned counsel has a relative justification. As I have already implied, the wage for single men is also artificial; but I need not reiterate the reasons already stated for this anomaly. It is more important to emphasize the dangers of levying a tax on male employees generally, in order to give an "artificial wage" to women. Two things seem reasonably certain. The first is that there will probably be, a substantial increase in the employment of women in the future. The tendency in this direction before the war has been accentuated by the war, and will very possibly be still more accentuated by the conditions following the conclusion of the war. The second thing is that the material well-being of the workers as a class depends as much on low prices as upon high wages. ${ }^{6}$ I do not mean that wages should not increase; I believe and hope that they will increase. But so far as the workers are concerned, what they really want is an increase in earning capacity, not merely an increase in nominal wages. In several cases before this court I have declared my reluctance to increase wages unless such increase could be taken out of profits. The principle affirmed by Mr. Justice Higgins would threaten a wholesale "passing on" in the prices of commodities, and so a reduction in the purchasing power of nominal wages.

In the second place, the principle of Mr. Justice Higgins, if generally applied, would act in practice with a strange caprice. The learned Judge takes the case of fruit-picking. In this, as in most unskilled industries, what would probably happen would be that, if men were available, they would be employed, whilst, if they did not happen to be available, women would be employed, and would be paid at rates of wage out of all proportion to their needs-the recognised standard of assessment-and out of all proportion to wages received by women who are engaged in other occupations which happen to be purely women's work, and are of certainly equal value from the point of view of the community.

In the third place, with reference to the broader social aspects of the question now under consideration, the trend of Mr. Justice Higgins's second principle, if put into general practice, would be to attract many women from the occupations which fit them for the life duties which the majority are called upon to fulfil, into occupations which have no value as a training for the performance of such duties. Closely associated with this aspect of the question is the problem of domestic aid. The problem has become increasingly important in Australia, among other reasons, on account of the vital importance to the community of maintaining the rate of increase of the population. The solution of the problem would be made increasingly difficult by awarding substantially higher rates for women workers in factories than are now current. No doubt there might be a marked improvement in the condi-

'Carpenters and Joiners' Case (1916-18) I8 S. A. I. R. I72-178. 
tions of domestic service which have hitherto prevailed; but taking facts as they are, there is the utmost difficulty, certainly amongst the working classes and persons of moderate incomes, in obtaining domestic help adequate to the upbringing of a family of even moderate size. Hence, in part, the growing sterility of the population-a serious menace to the future of Australia. If to-day, so many women would rather work in factories at low wages than assist in domestic service, what would happen if the wage for women in factories were doubled? It is an unpopular thing to state nowadays, but it is nevertheless broadly true, that women's true apprenticeship for her future career is to be found, not in the workshop or the salesroom, but in some form of training or apprenticeship directly related to wifehood and motherhood. I am fully aware that there are exceptional cases of women who do not marry, but an Industrial Court has to determine its action by reference to types rather than exceptions. The real question at issue, as regard women who do not marry, is not whether they shall not be paid a living wage with adequate margins for skill, \&c., but whether they shall be paid rates of wages avowedly assessed by reference to the needs of the bread-winner of a family.

In the fourth place, it might be urged-and indeed I suggested so much for the consideration of the parties in the course of the hearing of the recent case-that the apparent object. of awarding men and women equal minimum rates, namely, the protection of men from unemployment, might be met, at any rate in many industries, by limiting the proportion of women to men employed in the particular industry or grade thereof.

It is easier to find objections to a general principle relating to the rate of wage for women engaged in ambiguous occupations, than to propose any alternative scheme which would prove workable in practice, and, at the same time, reasonable and just in its operation alike to employers, to men and women employees, and to the community. In point of fact it is impossible to formulate a principle applicable in the case of ambiguous occupations to which some objections, more or less plausible, could not be urged. Nevertheless, with regard to any principle, the objections to it must be considered in their cumulative force. The principle which has been under examination appears to me to be open to objections so weighty that I feel it imperative to consider whether it would not be possible to formulate any alternative principle or principles. I shall begin with a statement of the more important factors of the problem to be solved. Many of these factors are in the nature of commonplaces, generally admitted as a matter of form, though apt to be lost sight of by individuals who are more anxious to justify cherished preconceptions than to arrive at just conclusions.

(I) The Rights of Women.-(a) To freedom in the choice of career, and $(b)$ to a fair wage. Neither right, as I shall indicate later, can be justly interpreted without reference to the good of the com- 
munity. What I wish to emphasize here is that women should not be treated as a mere means to an end; they are an end in themselves. Incidentally, I may remark that freedom in the choice of careers includes freedom to marry, and a right to support when married. The time may not have arrived when full legislative, administrative, or judicial recognition can be given to the claims of "the industrial mother." But Industrial Courts have given some recognition to the claims when assessing the living wage for men.

(2) The Traditional Organisation of Society.-According to this organisation, man is, or should be, the bread-winner. In other countries I have seen women, who should be engaged in domestic duties, earning the family income, while their husbands have been spending most of their time in indolence. Happily this is abnormal. Speaking generally, even as regards single women and single men, established tradition and morality impose upon the man and not the woman, the duty to save up for the initial expense of the home. I am aware that there are, in the traditional organisation of society, evils which an Industrial Court, so far as falls within its province, should seek to combat. The low wages paid to women workers in some industries may be quoted as an example. In I9I2 the average earnings of adult manual women workers was assessed in England at ros. Io $1 / 2 \mathrm{~d}$. per week. Per contra the duty of men to maintain their homes is a part of the traditional organisation of society which should be recognized by Industrial Courts as a general ground for differentiation in wages between men and women workers. Other grounds, related to the same source, might be found in the desirability that girls should be encouraged to receive a sound domestic training (either as a domestic help or in the home of their parents), and in the undesirability that women should be encouraged to indulge in a standard of expenditure so high that marriage may appear to them an intolerable sacrifice. The high wages which during the war have been paid to some women workers in England, have been alleged to act as a deterrent to marriage. If that be so, it is regrettable from the point of view of an Industrial Court. It is for the High Court of Parliament to assume the responsibility of sanctioning social revolutions, such, for example, as (a) authorising women of a certain income to have children without incurring the responsibility of marital life; $(b)$ releasing men from the responsibility of maintaining the home; (c) State endowment of motherhood, \&c.

(3) That an Industrial Court must take a broad view, dealing with types or classes rather than individuals, has been so generally recognised that I would hesitate to refer to the matter but for the fact that I have to address myself to a psychology which is, according to common repute, generally disposed to argue from the concrete instance. Even learned counsel in the recent proceedings before me did not escape the trap into which I should have been led if I ignored the duty to deal with classes rather than individuals. "A single woman," said Sir Josiah 
Symon, "may have a widowed mother to keep." I will even concede that she might have a widowed mother-in-law to keep! But the responsibility can hardly be a ground upon which to proceed in determining the wages of women workers in general. Doubtless the outluok of women will in time be broadened under the system of modern education, the freer life, and the greater opportunities offered to women in modern society; but the more advanced woman of to-day will freely admit that her sisters are apt to reason exclusively from concrete instances. As an example of what I mean, I may refer to the argument by some women that a single woman should receive as much as a single man. I have already shown why, on general and particular grounds, an Industrial Court must award the single man a living wage assessed by reference to the needs of the married man-grounds of which most do not apply to single women as a class.

(4) The comparative efficiency of women and men varies in different occupations. Sir William Beardmore, President in Igr6 of the Iron and Steel Institute, said:- "When it was found that the demands of the Government for a greatly accelerated production of shells required the employment of girls in the shell factory, owing to the scarcity of skilled workers, these girls in all cases produced more than double that by thoroughly trained mechanics-members of trade unions-working the same machines under the same conditions. In the turning of the shell body the actual output by girls, with the same machines and working under the same conditions and for an equal number of hours, was quite double that by trained mechanics. In the boring of shells the output also was quite double, and in the curving, waving, and finishing of shell cases quite 120 per cent. more than that of experienced mechanics." In the course of the hearing of the recent case before me, evidence was adduced to show the relative efficiency of men and women in the printing trade. A witness called on behalf of the employers deprecated employing women in substitution for men. The same witness dwelt upon the superior patience of women at routine work. He said also that women do not stay long enough to justify their being trained for the more important parts of the trade. I think it would be dangerous to attach literal importance to the passage cited from the presidential address of Sir William Beardmore. What women can do, and do do, in the fine fervour of a war enthusiasm, is no guide to what they will do under normal conditions. "There are," says Miss Rathbone, "in the eyes of most employers certain standing disadvantages of women's labor which have to be reckoned with. There is the fact that the law will not allow him to work her at night nor for overtime, except under rigid restrictions; that her liability to sickness (in most trades) is rather greater; that he cannot put her to lift heavy weights or to do odd jobs; that he cannot comfortably swear

'Economic Journal (March, 1918) 3. 
at her if she is stupid; that, in short, she is a woman, and most employers, being male, have a 'club' instinct which makes them feel more at ease with an undiluted male staff. Above all, there is the overwhelming disadvantage, if the occupation is a skilled one, that she is liable to go off and get married just as she is beginning to be of some use." 8 On the whole, I incline to the opinion that in most occupations women are potentially less efficient than men. In part, this may result from their training, environment, or the methods of industrial organisation which have frequently limited the work of women to an inferior or routine character. In part, however, the comparative inefficiency of women in a large number of occupations may be attributed to a physiological constitution which involves periods of relative inefficiency. Again, in many industries, the value of an employee is largely dependent upon an ability to cope with periods of exceptional stress. This ability of men as distinguished from women is not affected by the physiological conditions just referred to. Again, the value of an employee to an employer is in part dependent upon whether the employee regards the employment as a life's career or not. In the case of men, their occupation is their life's vocation; in the case of women, their occupation (beyond the domestic sphere) is, in most cases, transitory. The physiological effect upon the worker need not be emphasized. "It is," writes Miss Proud, "the uncertainty of a woman's vocation that forms its chief difficulty. One employer found that women would gladly attend cooking or housewifery classes when they knew they would shortly need to cook or keep house. But for Io years or more, from I4 years of age onwards, a factory girl's lifework is undecided. She usually declines to equip herself fully for either doubtful alternative. After ro years of drifting it is not likely that she will be perfectly prepared for either. The few years during which a youth's work is undecided are acknowledged to be difficult, but they are not universal, and are brief when compared with theşe years in a woman's life. It is not that women are not conscientious; they are often pathetically so. If there is a dreary monotonous task to be performed, which needs constant and minute attention, it is found that a woman's service is unsurpassed. It is not that women are not intelligent; individual women have again and again in various branches proved their worth. It is not that women are physically weak; individually they may be stronger than individual men, and, at any rate, physical strength is no longer the greatest factor in industry. Women are inferiors in the industrial world because they have not decided (except individually) that they desire to be otherwise, or at least that they desire to pay in training. the price of efficiency. Whether that price would be worth paying from a national point of view cannot be
guessed, and there is, on the part of employers, curiously little attempt

'Ibid. (March, I917) 59. 
to discover the truth in this connection. Where apprenticeship schemes for girls are introduced, they are on a different plan from those for boys, and they are hampered by the same difficulty of vocational uncertainty."

Sex disadvantages are the subject of reference in the judgment of Cussen J. ${ }^{10}$ Speaking of the rank and file of female workers, particularly, he said:- "Whatever else is alleged against the employers, it is not, so far as I am aware, contended that they are not capable of looking after their own interests, and can it be doubted that if the results from female clerks were equal to those from male clerks, the former would have been employed to a much greater extent? Yet except for special classes of work where also the females received much lower wages than the males (engaged in other classes of work) this was not the case. It follows as a corollary, if my view is right, that if the determination of the Special Board is adhered to, many females would lose their employment, and, as might have been expected, evidence was forthcoming that such a result would follow not, perhaps, in the case of exceptional, but certainly in the case of ordinary females."

(5) It is obviously the duty of a Judge of an Industrial Court to avoid regulations which would unduly hamper the industrial progress of the State. Both employees (male and female) and employers are concerned in this progress. The figures of the Commonwealth Government Statistician go to show that South Australia is not holding her own in the world of industry as compared with the other States. I see no reason to question the substantial accuracy of those figures more especially as they are in accord with common repute. While some of the figures might be explained by reference to the advantages enjoyed by Sydney and Melbourne with respect to the proximity of coal supply, superior marketing facilities, etc., they serve at the same time to emphasize the need for counterbalancing those advantages as far as may be practicable, provided a fair standard of wage is maintained. Otherwise, while seeming to help the employees, the Court will really be depriving them of employment. Of course, it is possible to argue that the State of South Australia should allow its manufacfuring industries to drift to other States whilst concentrating its effort on rural industries. But the argument is one for the High Court of Parliament rather than for the Industrial Court. The exact application of the "preservation of industry" to the question of the rates of wage for women can only be made in relation to particular industries. But one general principle emerges:-Assuming as axiomatic a living wage plus margins for skill, etc., data as to existing wages in one State have to be submitted to careful analysis before they can be accepted

${ }^{\circ}$ Welfare Work, 80-8r.

${ }^{10}$ Ig Argus L. Rep. I46. 
as a standard for another State. While they may be too low (having in riew the potential economy of high wages) they may also be so high that their imposition might imperil the industry, and inferentially prejudice employers and employees alike. Before a Court accepts the standard of wage set in another State, it should be informed of the relative conditions of the industry in the two States, the relative cost of living, \&c.

(6) Closely allied with the question of the conservation of industry is the question of how to regulate industry so as to secure the maximum production at the minimum costs of production. This latter question can scarcely be overlooked by Industrial Courts, even in normal times. But the times are not normal. "The world's poverty as a result of the war," said Mr. Parsons, K. C., in the recent case before me, "is so great that the world's work must be done at the lowest cost consistent with securing to the worker his or her reasonable needs, and a just secondary wage." Of course the desired result can only be attained by the co-operation of many agencies, including public and private. But it suggests, inter alia, industrial regulation along lines which would tend to promote the utilisation of all the available forces of the community in the work of production. Even before the war, the tendency of social progress was towards the elimination of the "social drone." The war has accentuated this tendency. When the war is over, financial obligations which have been incurred will impose on all classes of the community a new standard of efficiency. So far as women are concerned, the fact has a particular application inasmuch as in the past, prior to the period of marriage, a large number of women have neither contributed to industry, nor learnt domestic economy in a home. A further application may be found in the kind of work women are allowed to do. "In industry," writes Miss Rathbone, "the outbreak of the war found the women workers confined almost entirely, except in a few occupations traditionally their own, to the lowest, most illpaid, and unskilled occupations. The barriers that kept them out of the skilled trades were for the most part unrecognised by law, but they were almost completely effective, being built up partly of tradition, partly of trade union regulations, but mainly of the sex exclusiveness in which employers and employed made common cause. Against these barriers the women's movement had beaten itself for half a century in vain, but within two years the necessities of the war have broken them down-by no means completely, but to such an extent that it is plain that if re-erected they will have to be based frankly upon the desire of the male to protect himself from competition, and no longer upon the alleged incapacity of the female to compete."11

I am not holding a brief for that miserable "economy," if economy it may be called, which consists in "watching the pennies while the

\footnotetext{
${ }^{12}$ Economic Journal (March, 1917) 55-56.
} 
pound notes are flying out of the windows." There are to be found amongst us to-day some who seem to be obsessed by what they call "retrenchment." It was publicly stated the other day that the cost of Governments in Australia was $£ 800,000$ per annum. It does not fall within my province to discuss whether this is too high a price to pay for democratic institutions. I content myself with the remark that in the same year the cost of the Sydney strike to the Commonwealth was estimated to exceed $\pm 10,000,000$. I state these figures here because I feel that it is seldom realised that true economy should be sought in increased output (with all that increased output means), stability, co-operation, reasonable wages, etc. Sound national economy embraces the recognition of the need for securing such a return for work, whether mental or physical, as will maintain the worker in health and efficiency, and stimulate his or her ambition. The realisation of the fact, in its bearing upon maximum production at lowest cost of production, leads to the conclusion that lowest cost of production should be sought for, less in low rates of wages than in increased skill in the management, and in increased efficiency of the worker. But, whatever the rates of wage may be, a relatively low rate to women as compared with men is not necessarily open to the objection that it subsidises the employer at the expense of the employee. No doubt, especially in older lands, this objection is occasionally, and in some industries, justified. But in proportion as the price of commodities is controlled by active competition or by the intelligent supervision of public authorities, the subsidy, if so it may be called, goes, not to the employers, but to the community.

(7) Closely related to the matters just considered, is the prevention of unemployment either of men or women. Primarily, the problem of unemployment is one for the Legislature or the Administration; but an Industrial Court ought not to increase the difficulties of the Legislature or Administration in dealing with the problem. The South Australian Act of I9I2 precludes the Court from fixing lower than the living wage. But a judicial declaration of a living wage has no significance for those who cannot secure employment. So far as men are concerned, there is the obvious danger of their being driven out of employment by women working at a lower wage. On the other hand, so far as women are concerned, there is the obvious danger of excluding them from employments for which they are quite adapted, but not quite so efficient, as men, by fixing the same minimum rates for both men and women. As a woman writer already quoted remarks:-“The attempt to establish strict arithmetical equality between them goes further than is necessary to protect the men against unfair competition, and really weights the scale against the women." Again, speaking of women, there may be a class or classes with regard to whom it would be not in their own interests for the Court to prescribe even a living wage for women-a subject to which I shall return later. 
(8) The concept of justice, in an Industrial Court and Civil Courts respectively, varies. In Civil Courts, the Judge normally concentrates his thought upon the question of effecting "justice between the parties." In Industrial Courts, the Judge is impelled to take a wider range; he has to consider how a particular award may effect the parties in the particular industry, the class interests of employers and employees at large, and the welfare of the community. What I wish to stress here is that the good of the community is the supreme factor in the formulation of principles by an Industrial Court. I almost hesitate to speak of the "good of the community" because that expression has been so often used to serve the purpose or interest of a class or individual. Every conceivable condition of, or change in, social relations is alleged by one person or another, to be justified on the plea of the good of the community," when, in reality, the person has in his mind only the interests of a class, or, it may be, even an individual. A great principle has been prostituted to sinister ends. Obviously, since the community is made up of classes and individuals, the consideration of the good of the community must involve a consideration of the interests of classes and individuals. But there is a wide gulf which divides, or may divide, the purely class interest and that good of the community as a whole to which an Industrial Court must defer as the ultimate essential. The right of individuals or of classes must be defined in terms which are in harmony with the good of the community. One particular application of the formula that the good of the community is sovereign is found in the claims of that unrepresented party, the purchaser of commodities. Another application is that so long as men have "families to keep," and so long as there is no. State endowment of motherhood, the male employee is entitled to an allowance by way of extra wages in order that he may meet the expenses of his home. The rate of wage must include the claims of the "industrial mother," which, however inadequately recognised in the past, are not less deserving of recognition than the claim of the unskilled woman worker. Other applications of the sovereignty of the common good might be given. For the present it is sufficient to insist on the sovereignty as a fact which ought to control an Industrial Court in the formulation of principles. In interpreting the good of the community, the Court has not the same freedom as the Legislature; but, subject to existing law, it has a grave responsibility in this relation. The responsibility is especially apparent when the Court is called on to state principles of such far-reaching importance as those which relate to the regulation of the rates of wage for women workers. Of course it would be possible to give an award without any analysis of principles, to state results without their justification. But such a course is shirking responsibilities. Further, the Court may err in its principles. If it does, the clear statement of them enables the High Court of Parliament to vary the principles as regards future cases. 
SUMMARY OF FACTORS.

I do not pretend for a moment that my enumeration of factors is complete; but it indicates at once the more important things that have to be borne in mind, and at the same time, the extreme difficulty of arriving at just conclusions. I wish particularly to emphasize the danger which I am afraid is very commonly exemplified, of being obsessed by one or the other of the factors, to the exclusion of the others. That is the way to easy conclusions; but it is seldom the way to just conclusions. The factors must be viewed collectively if we are to avoid the bogs into which we would be led if we failed to observe a just sense of proportion. I now proceed to state the resulting conclusions to which I personally am led. It will be understood that I am only concerned with minimum, not maximum rates, that I speak of industries generally rather than of any one industry, and that I make no pretence to supersede supply and demand which must necessarily operate in favor of the worker, according to the state of the labor market.

THE IIVING WAGE FOR WOMEN.

Two questions arise for consideration:-(a) Are women workers entitled to a living wage? (b) If so, what should be the amount? As regards the first question I was referred in the recent case to a decision of the New South Wales Arbitration Court in I916. ${ }^{12}$ In the last mentioned case, Edmunds J., after conferring with Heydon J., refused to. enunciate as a general principle that every adult female worker is entitled to a minimum wage based upon the cost of living. The learned Judge held that the reason upon which the Court deduced the principle of the living wage for males was an inference from the Industrial Arbitration Act, and was not applicable in the case of women workers. The South Australian Industrial Arbitration Act of I9I2, however, (section 22) expressly stipulates that the.Court shall not award less than a living wage; and the section relating to the living wage applies equally to women as to men. I am aware that there are, as a matter of fact, industries or callings in which the majority of women employed are not in receipt of a living wage, and who, if awarded a living wage, would lose rather than gain. I can only say with regard to such cases that it would be proper to determine whether it was in the interests of the parties and the public to make an award at all. It might well prove, in some isolated cases, that women would prefer, when the issue was plainly set before them, to incur the disadvantage of a prevailing wage, or to accept some compromise between such prevailing wage and a true living wage, rather than run the risk of unemployment if that low rate were substantially increased. If such a case should come before me, I should feel it incumbent upon me to place the issues fairly

${ }^{21}$ (Igr6) I5 N. S. W., A. R. 453. 
before the parties so that they could determine the better course to pursue. If they chose not to insist upon an award of the Court, I should need very strong reasons to induce me to proceed with the hearing. Under section 2I (i.) of the Industrial Arbitration Act of I9r2, the Court has power to dismiss any dispute or matter or refrain from hearing or from determining a dispute or matter if it appears that the dispute or matter is trivial, or that, in the public interest, further proceedings by the Court are not necessary or desirable.

If, then, we assume that women are legally entitled to a living wage, the question arises as to what that living wage for women should be. Applying the statutory definition, it might at first appear that the living wage for women should vary not merely according to locality, but also according to the industry concerned. If, for example, it is shown that all women employed in a particular industry live at home with their parents, it is arguable that the living wage should not be as high as in an industry in which all the women live away from home. Mr. Justice Higgins, however, with reference to cases before the Commonwealth Court, uses without qualification the words "A woman or girl with a comfortable home cannot be left to underbid in wages other women who are less fortunate." Personally, I know of no industry in which the fact that a women does or does not live at home is a necessary qualification for her employment. The mere fact that all the women employed in a particular industry live in the homes of their parents, would not of itself prove a necessity for their doing so, or, that the custom, if so it might be called, was fixed and immovable. Other reasons enforce the argument to which Mr. Justice Higgins gives terse expression:-(I) While the question of value of work done cannot be accepted as an ultimate basis for the definite fixation of wages, it need not be wholly ignored. If men receive for unskilled labor " $X$ " per day, and if "Y" per day be the amount allocated to the male worker on the supposition that a man is or may become a breadwinner of a family, then " $\mathrm{X}$ "- " $Y$ " is a symbol which goes some way to indicate what a woman may claim a moral right to (living at home or not). (2) The adult woman worker who lives at home with her parents is under a moral duty to contribute a share in the upkeep of the family, and an Industrial Court ought not to fix the living wage for woman at a figure which would render the adequate performance of this duty difficult or impossible.

THE MINIMUM WAGE FOR WOMEN.

The minimum wage for women in an industry or grade must be fixed by reference to circumstances, conditions, \&c., of that industry or grade. The living wage is a matter primarily of actuarial calculation. The minimum wage in a particular industry, though it must not be less than a living wage, may be fixed at some higher figure on various 
grounds. Of these grounds, the most obvious is skill. In this connection I think that a useful distinction may be drawn between the primary minimum (applicable to the whole of an industry) and the secondary minimum (applicable to the several parts or grades of an industry). In assessing the proper marginal difference between the living (or a primary minimum wage, as the case may be) and the secondary minimum, regard should be paid to custom (ascertainable by reference to usage in the state or elsewhere) or to rates of wage in kindred occupations, or to such other standards or considerations (including the fact of male competition) as may be appropriate in the particular class. In an industry where both men and women are engaged, prima facie, the minimum rates for women might be expressed algebraically by reference to the minimum rates for men. Supposing a living wage for a man to be "X," and the minimum wage for labor in the particular industry to be " $\mathrm{X}$ " plus ro per cent., while the minimum wage for skilled labor in the same industry in a particular grade to be " $\mathrm{X}$ " plus 20 per cent., then the just remuneration for women would seem to be (supposing the living wage for a woman living apart from her parents to be " $Y$ ") " $Y$ " plus ro per cent. and " $Y$ " plus 20 per cent. respectively.

It will be apparent that the formula just indicated can only be taken as a rule of prima facie value. In the case of industries where it is desirable that men should be kept in employment, and there is a real danger of their being competed out of employment by women labor, a very difficult situation arises. It has been argued that it would not be to the interests of the community that men should be kept in employment (if women were capable of doing the work) at the price of paying women a man's minimum. On the other hand it is necessary to remember the reasons, some of them very cogent, why women should not be encouraged to do work, which normally and properly is done by men, at the cost of creating unemployment among the men. I suggest that with respect to any industry or grade, where the prima facie formula above indicated is challenged, evidence should be adduced to show that it is desirable, having in view the interests of all parties and of the community, that men should be retained in that industry or grade, even though such retention might involve some departure from the formula in question. Where such evidence is satisfactory, there are several alternatives open to an Industrial Court:-(I) To fix the same wage for women as for men; (2) to fix a ratio wage where it is proved that the average woman is not of equal value to the employer; (3) to exclude women; (4) to accept the prima facie mode of assessment, but to limit the proportion of women who may be employed by any particular employer in any particular industry or grade.

In choosing between the alternatives suggested, the factors to which I have referred, and all the conditions of the industry under adjudi- 
cation, must be considered cumulatively. The task of choosing may often be one of extreme delicacy and difficulty. The legitimate claims of women, both to a free choice of career and to a fair wage for work done, have to be reconciled and harmonised with the like claims of men. Women must not be denied a living wage in any case; but apart from this, and apart from their just claim to marginal differences, the obligation is cast upon an Industrial Court to see that women are not doomed to occupy the unenviable roll of blacklegs in the sphere of essentially male occupations. In the discharge of this obligation, the Court will have necessarily to sacrifice that will-o'-the-wisp of uniformity of wage to women workers. The difficulty of securing justice to women's claim to a fair wage can only be harmonised with the just claims of the community, the employers, and the men wage earners, if we face the problem as it presents itself in the varying conditions of different industries. Beyond what $I$ have already said, $I$ do not at present suggest any further general rule as to the choice between the various alternatives indicated where the Court has to deal with minimum rates of wage for women in occupations in which men are also employed, and in which it is desirable that men should continue to be employed. We live in a progressive age; and an Industrial Court has to beware of what I may describe as the premature crystallisation of principle, lest such crystallisation should have the practical effect of impeding instead of assisting industrial stability in the future.

SUMMARY OF PRINCIPLES.

I. All women workers are entitled to a living wage and to a reasonable addition to that wage by way of marginal differences.

2. The living wage for men must include the claims of the "industrial mother," and the home over which she presides.

3. In fixing the primary minimum wage for women in an "ambiguous occupation," regard must be paid to the question whether it is necessary in the interests of male workers and the community, to prevent men from being competed out of employment by cheap female labor. Where it is proved to be necessary-and the proof must depend upon the evidence adduced with respect to the particular industry under adjudication-then the Court should resort to one or other of the various alternatives indicated.

PROGRESS: SUPPIY AND DEMAND.

I have endeavored to frame the broad outlines of a scheme for dealing with the vexed question of the relative rates of wage for men and women. I may add that I am not so vain as to imagine that the scheme I have submitted is open to no objection. As I have already suggested, it is impossible to give full effect to all of the various factors of the 
problem. What an Industrial Court has to do is to avoid at all costs the danger of obsession by particular factors. It has to look at all the factors of the problem together, and harmonise and reconcile them as best it can. I should like also to add that if in particular cases an Industrial Court errs in its solution of the vexed problem under consideration, to some extent at least, its errors may be rectified by supply and demand. An Industrial Court does not impose maximum wages. Given the minimum fixed by an order or an award, it is surely a paying proposition for employers to pay higher than the minimum to the more competent workmen in order to retain their services, and to stimulate the less competent. As regards a woman, whatever wages this Court may fix are minimum rates which leave to individual women full and free right to refuse to accept employment save at some higher rate. The law of South Australia prohibits the lock-out and the strike. Subject to this prohibition, the competition between employers for the services of men and women is not designed to be interfered with. Even if the South Australian Court imposes a minimum wage for women who do a certain class of work, that would not prevent individual women from insisting on a higher rate as a condition to accepting employment. To what extent women would be able to avail themselves of this right would largely depend, of course, upon the state of the labor market. I am aware that, in the past, "supply and demand" in relation to wages has been anathema to many reformers. It has been looked upon as a pretext for sweating and similar evils; but the principles which I have formulated, in stipulating that women should receive at least a living wage, and a minimum wage for skill, \&c., should remove an objection which has been felt, and naturally and properly felt, to the unrestricted operation of supply and demand in relation to labor. In the recent case I was referred to the fee received by women doctors as an argument for equal pay for the sexes. But the wages, salaries, earnings, or fees of women doctors are regulated by conditions over which the South Australian Court has no cognizance. Those conditions may at some future date be applicable to women workers generally. If this should happen, it would amount to a social revolution. But an Industrial Court must have regard to existing conditions; and I may express the hope that the time will not come when women workers in the field of industry should ignore the claims of the "industrial mother," who has to keep the familly going out of the husband's wages. 